\title{
Multiscapes and Urbanisation: The Case for Spatial Agroecology
}

\author{
Richard Morris ${ }^{1,2, *}$, Shannon Davis ${ }^{2,3}$, Gwen-Aëlle Grelet ${ }^{4}$ and Pablo Gregorini ${ }^{1,2}$ \\ 1 Department of Agricultural Science, Faculty of Agriculture and Life Sciences, Lincoln University, \\ Lincoln 7674, New Zealand; pablo.gregorini@lincoln.ac.nz \\ 2 Centre of Excellence Designing Future Productive Landscapes, Lincoln University, \\ Lincoln 7674, New Zealand; Shannon.Davis@lincoln.ac.nz \\ 3 School of Landscape Architecture, Faculty of Environment, Society and Design, Lincoln University, \\ Lincoln 7674, New Zealand \\ 4 Manaaki Whenua-Landcare Research, 54 Gerald Street, Lincoln 7640, New Zealand; \\ greletg@landcareresearch.co.nz \\ * Correspondence: Richard.Morris@lincoln.ac.nz
}

Citation: Morris, R.; Davis, S.; Grelet, G.-A.; Gregorini, P. Multiscapes and Urbanisation: The Case for Spatial Agroecology. Sustainability 2022, 14, 1352. https://doi.org/10.3390/ su14031352

Academic Editor: Alejandro Rescia

Received: 30 December 2021

Accepted: 19 January 2022

Published: 25 January 2022

Publisher's Note: MDPI stays neutral with regard to jurisdictional claims in published maps and institutional affiliations.

Copyright: (C) 2022 by the authors. Licensee MDPI, Basel, Switzerland. This article is an open access article distributed under the terms and conditions of the Creative Commons Attribution (CC BY) license (https:// creativecommons.org/licenses/by/ $4.0 /)$.

\begin{abstract}
The two most significant signatures of the Anthropocene-agriculture and urbanisationhave yet to be studied synoptically. The term periurban is used to describe territory where the urbanising trend of the planet extends into multiscapes. A periurban praxis is required that spatially reconciles urbanisation and agriculture, simultaneously permitting urban growth and the enhancement of critical ecosystem services provided by agricultural hinterlands. This paper presents a synthesis of four fields of ecological research that converge on periurban multiscapes-ecological urbanism, landscape ecology, ecosystem services science and agroecology. By applying an ecosystem services approach, a diagram is developed that connects these fields as a holistic praxis for spatially optimising periurban multiscapes for ecosystem services performance. Two spatial qualities of agroecology - ES Density' and 'ES Plasticity' - potentiate recent areas of research in each of the other three fields-ecology for the city from ecological urbanism, landscape metrics from landscape ecology (particularly the potential application of fractals and surface metrics) and ecosystem services supply and demand mapping and 'ES Space' theory from ecosystems services science. While the multifunctional value of agroecological systems is becoming widely accepted, this paper focuses on agroecology's specific spatial value and its unique capacity to supply ecosystem services specifically tailored to the critical ecosystemic demands of periurban multiscapes.
\end{abstract}

Keywords: agroecology; periurban; multifunctionality; ecosystem service bundles; landscape metrics; land-use planning

\section{Introduction}

The term 'multiscape' can be considered a portmanteau derived from 'multifunctional' and 'landscape'. Multifunctionality, in the context of rural landscapes, refers to synergetic relationships between food and fibre production and other ecosystem services [1]. Multiscapes embody multiple processes and objectives rather than the conventional agricultural preoccupation with productivity. Gregorini and Maxwell (2020) elaborate further, depicting multiscapes as adaptive spatio-temporal simultaneities, integrating functionalities, such as food production, biodiversity, animal health and human nutrition, with shifting social/cultural perceptions of productive landscapes [2]. In this paper, we identify urbanisation as an additional layer to be considered in multiscapes; in doing so, we make the case for a different way of considering farming. Instead of regarding multiscapes as mainly productive landscapes interspersed with ancillary human settlements, the reality is that continually evolving thought, social, land, food, health, wildscapes [2] must account for the increasingly pervasive role of urbanisation. There is no consensus as to which of the two most visible anthropogenic signatures_-urbanisation or agriculture-has the more negative impact on natural environments and the ecosystem services they provide. Depending 
on which literature and perspective is chosen, urbanisation [3-5] and agriculture [6-10] will be either key components to the transition to sustainability or major threats to sustainability. Either way, there has yet to evolve a unifying conceptual or methodological praxis $[11,12]$ that (a) looks at the two synoptically and (b) presents spatial mechanisms to reconcile urban growth with the enhancement of the critical ecosystem services provided by agricultural hinterlands.

To develop this discussion, we present a conceptual model to illustrate the development of such mechanisms. The model is built around a fresh synthesis of four ecological fields-ecological urbanism, landscape ecology, ecosystem services science and agroecology - that are relevant to the spatial analysis of and design intervention into periurban multiscapes. Periurban describes the amorphous transition zone where multiscapes are shaped by the convergence of urbanisation and agriculture, as well as 'natural' ecosystems [13], and serves as the ideal laboratory to test our model. Globally, periurban multiscapes are increasing in physical size, the number of human inhabitants and in subsequent pressures placed upon environments at a greater rate than either city or countryside [14]. Devising a methodology to foster the ecosystemic reconciliation of urban and rural is, therefore, critically important. Throughout this review, a diagram is used to demonstrate the convergence of each field on the periurban zone and new interdisciplinary connections between ecological urbanism, landscape ecology, ecosystem services science and agroecology (Figure 1). What emerges from this diagram is a different way of considering farming, one that utilises agroecology's spatial capability to operationalise urban and rural reconciliation, to couple the expansion of human settlements with the multifunctionality of rural landscapes. Central to this overall discussion is the ecosystem services approach. As defined in more detail below, ecosystem services are the provisioning, regulating and cultural services that nature provides and that are indispensable to human prosperity and survival [15]. While the term ecosystem services may imply an anthropocentric perspective of nature-serving-man, we retain its use in this paper for simplicity as most of the literature reviewed is still based on that term. However, it is also important to note the original concept of ecosystems services is also being challenged for being incompatible with transformative changes that are occurring under climate change [16]. Being cognisant of this ongoing discussion, for the purposes of this review, we view ecosystem services as a paradigm used to comprehend human's relationship with the larger functionality of nature, perceived or unperceived, direct or indirect [17]. As we propose in this paper, agroecology's future periurban role is underpinned by two exclusive spatial properties that it exhibits in relation to ecosystem services. Firstly, as managed ecosystems structured around the stacking of multiple ecosystem services [18,19], agroecological farming systems provide a high concentration of ecosystem services, or 'ES Density'. Agroecology delivers ecosystem services with a spatial efficiency that distinguishes it from other periurban land-uses. Secondly, as managed ecosystems are based on diversity as a guiding principle, agroecology retains a high level of plasticity in the ecosystem services it provides [20,21]. We suggest that agroecological systems can apply this 'ES Plasticity' to the critical periurban function of spatially matching the supply of ecosystem services to specific ecosystem services required by expanding human settlements. Our conceptual model asserts that agroecology, based on its unique combination of ES Density and ES Plasticity, be viewed as an integral component of urbanisation. Its spatial efficiency makes it highly suited to the competition between land-uses for periurban space. At the same time, its functional dexterity optimises the use of this space, deploying a range of nature-based solutions to address systemic challenges, including climate change, nutritional security, biodiversity loss and human health. 

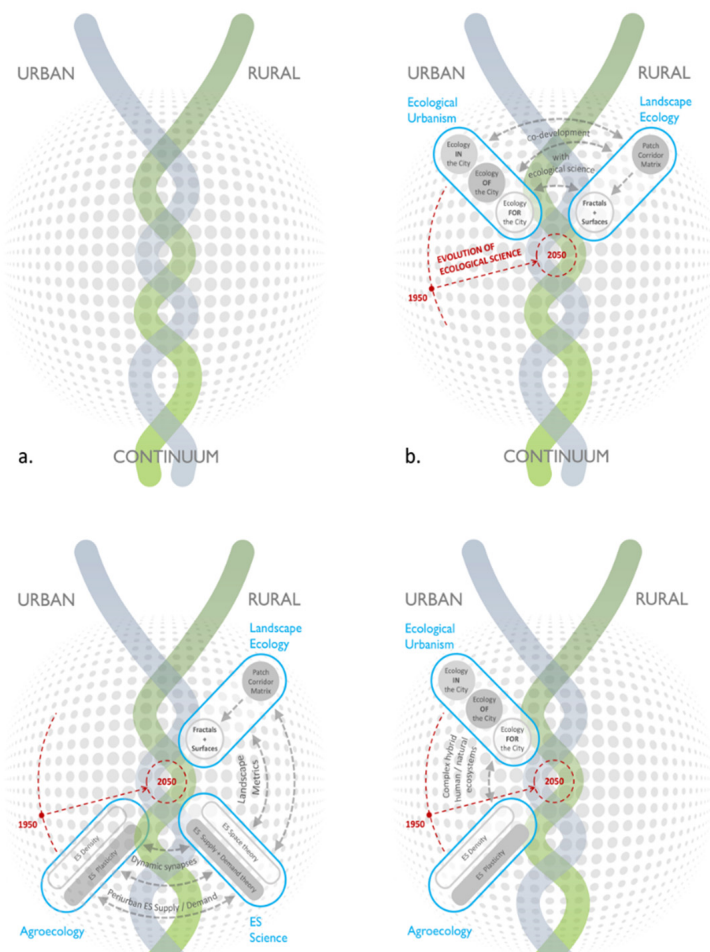
CONTINUUM
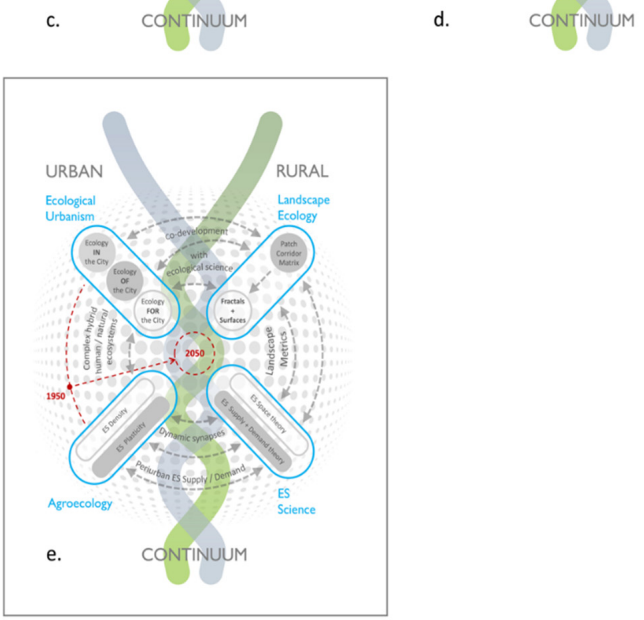

Figure 1. A conceptual model for spatial agroecology: Four ecological fields of research-ecological urbanism, landscape ecology, ecosystem systems science and agroecology—as being highly relevant to the analysis of and intervention into the periurban zone. The timelines shown in red are arbitrary, intended to show the historic development of these four fields and the process of convergence and developing interrelations between them in the critical decades ahead. (a). The helix running vertically represents the dissolution of urban and rural dichotomy into the spatial and temporal continuum, spanning the entire rural to urban spectrum that characterises the present periurban zone. (b). Ecological urbanism and landscape ecology establish an ecological lens to view the periurban multiscapes. Landscape ecology provides quantitative measurement of periurban heterogeneity, while ecological urbanism reinforces the human-natural composition of this heterogeneity. (c). Ecosystem services sciences, particularly the mapping of ecosystem services supply and demand and 'ES Space' theory, mediate between landscape ecology's interpretation of landscape pattern and agroecology's unique properties of 'ES Density' and 'ES Plasticity' to provide adaptive ecosystem services to periurban multiscapes. (d). At the close of the circular diagram, a future discourse between ecology for the city and agroecology - the lingua franca of adaptative complexity providing the unforeseen potential to inform future periurban metabolisms and morphologies. (e). The completed diagram indicating convergence of all four fields of research in the periurban zone and the respective interrelationships between fields of research as detailed in this review. 
This review is structured in the following sections, mirroring the development of the diagram in Figure 1:

1. Multiscapes on an urbanising planet-this section describes the global ecological significance of periurban multiscapes, the changing nature of their composition and the context for our conceptual model.

2. Ecological urbanism and landscape ecology-this section describes the parallel evolution of ecological urbanism and landscape ecology from the 1950s to the present day. Developments in ecological science during this time embody a transition from mechanistic and reductionist visions of reality to new understandings of an interconnected biosphere, what Fritjof Capra refers to as 'Earth's living patina' [22]. This transition coincides with social and morphological changes in the nature of the periurban zone occurring during this same era, deepening the relevance of both disciplines to periurban analysis and design intervention.

3. Ecosystem services science- this section reviews the literature falling under the broad topic of ecosystems services science. Specific attention is paid to recent developments in the quantitative understanding of landscape-scale ecosystem services supply and demand and the potential commonalities they have with learnings from landscape ecology. For example, the discrete spatial mapping of ecosystem services flow could provide new pathways for sustainable intervention in periurban multiscapes.

4. Agroecology - this section expands on the inherent and emergent spatial characteristics of agroecology that make it well-suited for embarkation on these pathways.

With each section, the diagram is developed accordingly, its overall circular part suggesting that an interdisciplinary convergence of these four fields of research is required to develop a periurban praxis, a conceptual spatial model for the analysis and design intervention into the urbanising reality of multiscapes.

\section{Multiscapes on an Urbanising Planet}

Multiscapes exist on an urbanising planet and will increasingly be influenced by urbanisation. By 2050 it is projected that more than two-thirds of the world population will live in urban areas [23,24]. By the end of this decade, populous nations, such as Argentina, Brazil, South Korea and Venezuela, will be more than $90 \%$ urban; Colombia, Mexico, The Philippines and Turkey will be above 75\% [25]. This influx of population to cities could imply a lessening of urban presence in rural multiscapes. However, both the social-economic and the physical spheres of urban influence are growing outwards. The physical extents of cities across all population scales are expanding faster than their population rates [14,26]. 'Budding outward' is the dominant typology of urban expansion worldwide [27]. The outward budding is not perfectly centrifugal but more like a diffuse asymmetry of conversion and fragmentation of rural hinterlands [28]. The space-filling characteristic of urban sprawl is also lateral, infilling as smaller centres are subsumed [28,29], and centripetal, with around a quarter of the world's urban population aggregating in slums and informal peripheral settlements [30].

Most forms of urban expansion are correlated by default with unsustainability in terms of greater energy consumption, air and water pollution, loss of natural habitats and loss of ecosystem services [4,31-33]. In general terms also, urban expansion is predominantly periurban expansion [26], and consequently, periurban landscapes bear the burden of these negative impacts [26,34]. Historically, cities have been located either in lands of high productivity or alternately as places to control logistical flows to and from areas of high production or to defend areas of high production [35]. The consumption of productive land by urban expansion is discussed widely [36-41]. However, the net impact on the regulating ecosystem services supplied by periurban areas (such as flood protection, microclimate regulation, water filtration, waste decomposition, nutrient recycling and pollution mitigation) that are critical to urban survival is less tangible than provisioning services (such as food production), and therefore, less discussed [13,15,42,43]. 
Alongside the increasing significance of the periurban zone globally, in terms of its physical size, its human population and its ecological impact, the definition of what is considered to be periurban is also changing [44]. Traditionally an urban/periurban/rural trichotomy may have been perceptible, but this buffer zone functionality has now essentially dissipated, with periurban multiscapes now broadly described in terms of a spatial and temporal continuum spanning the entire rural to urban spectrum [45-48] (Figure 1a). This continuum is highly transitory and heterogeneous, so much so that distinct biophysical, morphological and socioeconomic contrasts between urban and non-urban lands are becoming less discernible and less relevant [49-52]. The following sections will address gaps in the four research fields of ecological urbanism, landscape ecology, ecosystem services science and agroecology that are revealed when they individually converge on this periurban continuum. We suggest that a number of these gaps are addressed when agroecology is reconsidered as a spatial mechanism, which in turn involves novel synthesis of these fields. For instance, we submit that neither ecological urbanism nor landscape ecology has yet to adequately recognise agriculture's potential as a mechanism for supplying regulating ecosystem services. Regarding ecosystem services science, recent research into ecosystem services supply and demand has focussed on the composition of landscapes generating ecosystem functions, but not yet the role played by landscape configuration. Similarly, research into agroecological systems has identified the spatial properties of ES Density and ES Plasticity but has yet to either combine them or consider them as a spatial planning mechanism.

\section{Ecological Urbanism and Landscape Ecology}

As their names indicate, ecological urbanism and landscape ecology are branches of the ecological paradigm applied to human settlements and their hinterlands since the turn of the twentieth century. The major figures of twentieth-century urban theory-Howard, Geddes, Leopold, Mumford and McHarg [53-55]—are also influential on landscape ecology theory. This review notes, however, that no specific reference is made to agriculture as an ecosystemic actor throughout the entire evolution of this paradigm. Notwithstanding this, a summary of the evolution of these two disciplines remains relevant to understanding agroecology's potential future ecosystemic role in periurban multiscapes.

The separate scientific disciplines of ecological urbanism and landscape ecology emerged in the early 1950s, and the subsequent development of each discipline reflects the evolution of ecological sciences since the middle of the twentieth century [56] (Figure 1b). They began as subdisciplines of 'ecology' in the original, purely biological sense, namely, as the study of relations between organisms and their environment [57]. By the end of the twentieth century, both disciplines had departed from mechanistic and reductionist visions of reality, resulting in new understandings of the biosphere and human inhabitation of it $[12,58]$. Similarly, in both disciplines, the concept of ecosystems existing in a state of equilibrium has progressed to acknowledge a new reality of heterogeneous systems that operate in states far removed from equilibrium [29,59-61]. These parallel trajectories, from linear/dualistic thinking towards a systemic approach, have brought them to present research themes that are relevant to the development of a synoptic urban/rural methodology for analysis of, and intervention into, periurban multiscapes.

The evolution of ecological urbanism is divided by Pickett et al. (2016) into three main paradigms: (1) ecology in the city; (2) ecology of the city; and (3) ecology for the city [56,62]. Ecology in the city emerged in the 1950s, its name derived from a scientific focus on non-human enclaves existing within the urban matrix [63]. Urban areas, in general, were shunned by ecologists for most of the twentieth century [4], reflecting the prevailing binary distinction between cities and nature and between human and 'natural' ecosystems [63]. While the habitat types chosen for ecological study, such as urban forests, parks, cemeteries, wastelands, streams and wetlands, reflect the diversity of ecologies within cities, they were usually analogous to those outside of cities in terms of natural homogeneity [56]. Ecology of the city emerged in the 1980s and represented a significant shift in the understanding 
of urban heterogeneity (and, by extension, periurban heterogeneity). Where ecology in the city studied ecosystems occurring in cities in comparison with other environments, ecology of the city looked at these ecosystems as integral parts of their surroundings while acknowledging humans as components of these ecosystems [64]. Cities and their aggregate internal and external parts were read as ecosystems in and of themselves, which could be analysed with the same parameters of measurement and on the same terms as natural ecosystems [52]. It was established that the spatial heterogeneity of urban ecosystems plays a key role in their overall ecological function $[65,66]$. Translated to the periurban context, urban sprawl became understood as a human-natural phenomenon: a complex adaptive system comprising socioeconomic functions (real estate markets, commercial and cultural activity and transportation infrastructure) and biophysical, morphological factors (regional climate, hydrology and topography) [67]. Ecology of the city also recognised that the components within this complex adaptive system could themselves be complex coupled human-natural elements [42]. In periurban multiscapes, such coupled ecosystems include agroecological farming systems, along with buildings and sealed surfaces, infrastructure, waterways, parks, forests and gardens, all of which can be considered potential drivers of ecosystem structure and function.

Ecology for the city emerged in the 1990s from an ethical realisation that for ecological urbanism to be of greatest use, it must extend beyond the analysis of ecology of the city and develop methods for sustainable intervention [56]. Highlighting the significance of periurban multiscapes, Alberti (2016) asks if 'the emerging patterns of urban agglomeration affect the probability that we will cross thresholds that will trigger abrupt changes on a planetary scale?' [59]. This new impetus for design intervention, a so-called 'design-ecology nexus', introduces a further level of complexity [68]. It asserts that the manipulation of settlement patterns (i.e., periurban morphology, land use distribution and connectivity) can influence ecosystem dynamics and their ecological resilience [69]. The design-ecology nexus, as described by Alberti, focuses on novel coupled human-natural systems, citing emerging evidence that the unprecedented speed and complexity of environmental change driven by urbanisation can lead to unprecedented eco-evolutionary changes over a relatively short timescale [59]. This challenges the default correlation of urbanisation with unsustainability; instead, potential new ecological patterns, processes and functions emerging from coupled human-natural systems, such as agroecological systems, could have significant positive implications for ecological and human well-being.

In summary, ecological urbanism, and in particular ecology for the city, provide a basis for understanding periurban multiscapes as complex adaptive coupled human-natural systems. This presents the potential for new and positive ecological patterns, processes and functions to emerge from this fabric. In parallel, landscape ecology has developed a comprehensive range of quantitative tools, or 'landscape metrics', with which to analyse and engage with the spatial configuration of these systems and ecological processes [70,71].

Landscape ecology's original 1950s definition aimed to understand the functional correlation between landscape features and their numerous ecological interdependencies [72] Although a relatively young discipline, it has since diversified into a wide spectrum of research agendas, which Kirchhoff et al. (2012) identify as ranging from social sciences to various subdisciplines of ecological science in its original, purely biological sense [57]. As we are primarily interested in the spatial design of periurban multiscapes, the focus is placed on the brand of highly quantitative, pattern-process oriented landscape ecology that has developed mainly in the United States [73]. Seminal to this branch of landscape ecology was Forman and Godron's (1981) paper, which conceived the terms 'patch, corridor, and matrix', establishing a paradigm that remains near uniformly applied across this field of work and forms the basis for most landscape metrics [74,75] (see Figure 2). Landscape metrics are intended not just as tools for analysis, but also as tools for intervention, aligning with a fundamental premise of landscape ecology set out by Wiens (1995) that 'the explicit composition and spatial form of a landscape mosaic affect ecological systems in ways that would be different if the mosaic composition or arrangement were different' [76]. In other 
words, the manipulation through the design of landscape patterns occurring in periurban multiscapes will result in changes to ecosystem function, which might also be described as a 'design-ecology nexus'.

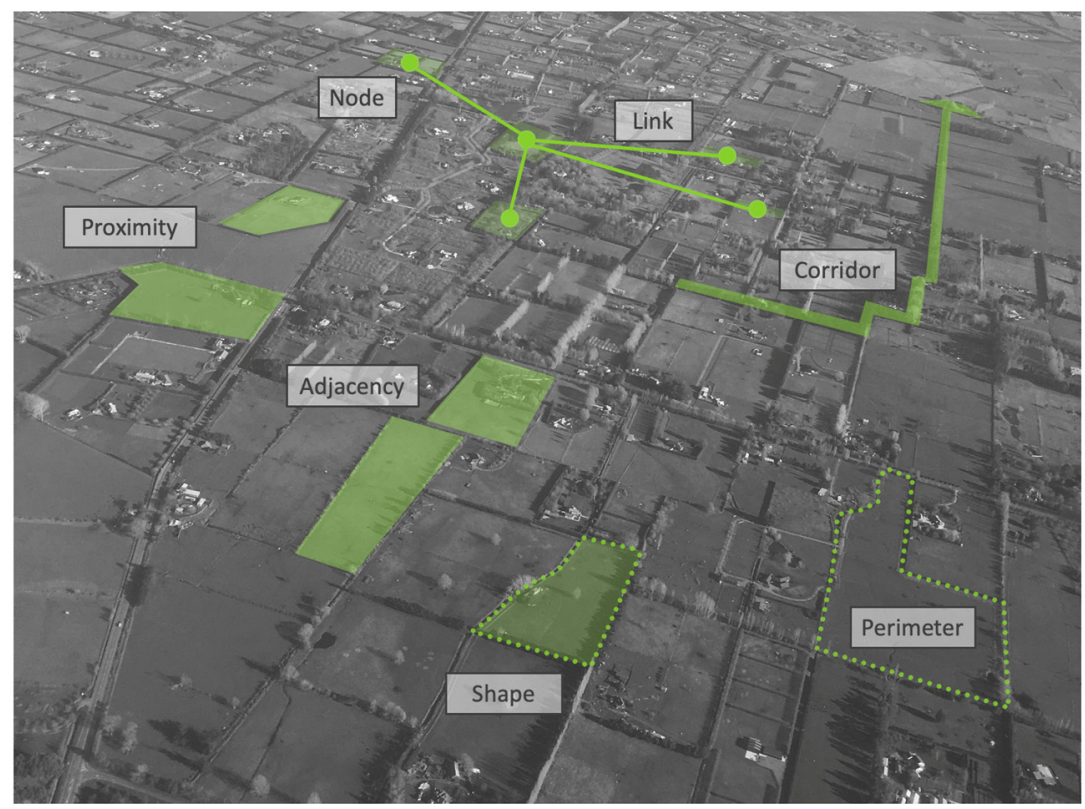

Figure 2. Illustration of the 'patch, corridor and matrix' concept applied to a periurban area. Examples of spatial configurations analysed by landscape metrics are shown, as well as the essential components of connectivity metrics (nodes and links). Image courtesy of the authors.

Landscape metrics are widely used to describe the patterns of landscape mosaics and their relationship to land use/land cover (LULC), biodiversity distribution, ecological processes and ecosystem functions $[28,77]$. Such mosaics are largely shaped by the ecosystem services demanded by society [78,79], the edges of human-made mosaics prevalent in periurban multiscapes being characterised by a strong contrast between patches and long, simplified edges, in contrast with the complex and convoluted edges occurring in nature [80]. There is now widespread use of LULC designations as proxies for ecosystem services [81], although significant research into testing and understanding such correlations remains [82].

Landscape metrics have been divided by Turner and Gardner (2015) into the four groups-spatial configuration metrics, connectivity metrics, fractals and surface metrics [74]. The two closely linked concepts—spatial heterogeneity and scale multiplicityrecur across all four of these groups $[60,83,84]$. Wu et al. (2000) assert that spatial heterogeneity is the most fundamental characteristic of all landscapes-fundamental to ecosystem processes, redundancy and resilience $[85,86]$. Such processes operate on a wide range of scales (i.e., paddock, farm or multiscape), and their characteristics are markedly associated with the specific scale being assessed [60,87]. Thus, analysis across a range of scales is imperative for understanding the structure, function and dynamics of landscapes [88]. The first two groups of landscape metrics are based on the categorical classification of landscape data, i.e., discrete, spatio-temporally static landscape elements (Figure 2). However, even with high-resolution LULC data, these two-dimensional approaches are sub-optimal for representing the complex reality of periurban mosaics $[45,51,75]$. As well as being static representations of what is essentially a dynamic environment, they effectively bypass the complex processes occurring within each discrete landscape element. This includes the coupled human-nature interactions identified in ecology of the city. Consequently, this also precludes the potential to analyse and intervene in the co-evolution of the novel, and potentially beneficial, systems as suggested by ecology for the city. Nevertheless, certain landscape metrics from the first two groups remain relevant to analysis and intervention 
into periurban multiscapes. A range of spatial configuration metrics, for instance, that address 'aggregation' look at the dispersion and interspersion of different patch types [89]. Contagion (or the 'clumpiness' or dispersed pattern of LULC types) is an index demonstrated to be effective at representing overall landscape change $[74,90])$.

The third category, fractals, which comprise naturally-occurring self-replicating patterns across a range of scales have been suggested as an alternative to describe natural landscape heterogeneity [80]. Laca (2021) has applied fractals to the analysis of foraging behaviour [91], building on established correlations between fractal configurations and biodiversity. By reversing this model and designing fractal-like spatial configurations of ecological communities, Laca hypothesises that ecological functions could be channelled to deliver specific ecosystem services [91]. Extending this hypothesis, the concept of spatial agroecology we are proposing asks if the spatial configuration of LULC, achieved by leveraging agroecology's ES Density and ES Plasticity, could be used to deliver specific ecosystem services demanded by periurban multiscapes.

The fourth category, surface metrics, utilises changes in landscape texture to analyse the more continuous (rather than categorical) heterogeneity characteristic of periurban multiscapes. McGarigal and Cushman (2005) introduced the 'landscape gradient' model, a general conceptual model of landscape structure based on continuous rather than discrete spatial heterogeneity [92]. In this model, the underlying heterogeneity is viewed as a three-dimensional surface that can be used to represent any ecological attributes of interest [92]. Drawing from metrology (the study of surfaces derived from the field of structural and molecular physics), key surface metrics include surface roughness, the shape of the surface height distribution, angular texture and radial texture [89]. However, a clear correlation between surface metrics and ecosystem functions are yet to be proven, and their potential for generating new insights about pattern-process relationships remains to be determined $[93,94]$.

In summary, ecological urbanism and landscape ecology each contribute to the understanding of agroecology's role in the spatial analysis of and design intervention into periurban multiscapes. The most evolved form of ecology for the city is useful for the diagnosis of complex coupled human-natural systems that typify the periurban zone. Landscape ecology, on the other hand, has a range of quantitative tools that can be utilised to detect correlations between the configuration of these systems and ecosystem performance. Although most landscape metrics are limited by their static analysis of landscapes, they have not been extensively applied to the field of ecosystem services science, which is detailed next. As will be discussed, these static measures, along with the development of the two approaches of fractals and metrology, may have significant relevance when the supply and demand of ecosystem services is quantified, correlated to LULC and then precisely mapped across periurban multiscapes.

\section{Ecosystem Services Science}

Ecosystem services science gained significant momentum and prominence following the publication of the UNEP's Millennium Ecosystem Assessment (MEA) in 2005, which categorised ecosystem services into four broad types-provisioning, regulating, cultural and supporting [95]. To avoid 'double-counting', these are commonly reduced to three 'final' services-provisioning, regulating, cultural [96] — contributing to human welfare through a supply of natural goods (provisioning), the control of material and energy flows towards a reduction in natural hazards (regulating) and by opportunities of (cultural) experiences in connection with nature and landscape [97]. The MEA was preceded by Daily's seminal text (1997) that comprehensively set out the range of ecosystem services and highlighted human reliance on them [15]. Critically, Daily identifies regulating and supporting ecosystem services, which are critical for life on Earth, as 'pervasive and yet virtually unknown by most humans' [15]. As we noted earlier, such inconspicuous services (including flood protection, microclimate regulation, water filtration, waste decomposition, nutrient recycling and pollution mitigation), so critical for adaptation to future environ- 
mental challenges, are generally overlooked when periurban land-uses are only studied at myopic, coarse scales [42].

Ecosystem services in this way represent the critical interface between human, natural and hybrid human/natural systems - an interplay between the ecosystem diversity and human activity [98]. Following the MEA, ecosystem services science developed around the analysis of this interplay, around ecosystem biodiversity and functionality, and the concept of ecosystem services trade-offs [99]. Ecosystem services trade-offs occur where increases in one ecosystem service or human activity typically result in either the enhancement or the reduction of other ecosystem services $[100,101]$. To achieve more ecosystem services synergies and reduce ecosystem services conflicts, the relationships between corresponding multiple ecosystem services and the mechanisms behind these relationships has emerged as critical to the management of sustainable landscapes [102-104]. Seminal research into multiple ecosystem services by Bennett et al. (2009) and Raudsepp-Hearne et al. (2010) observed that certain groups of ecosystem services appear together consistently, introducing the term 'ecosystem services bundles' [102,104]. For example, Yang et al. (2015) surveyed twelve ecosystem services across twenty-two urban-rural systems. Among the supply bundles emerging were consistent synergies between carbon sequestration, soil protection, water conservation and forest recreation [105] (i.e., between regulating and cultural ecosystem services). A quantitative review of ecosystem bundles, in particular, underlines a recurrence of synergies between regulating ecosystem services, showing consistent correlations between habitat protection, climate and atmosphere regulation, pest and disease control, soil quality and water quality [106].

As can also be seen from this table (Figure 3), ecosystem service bundles may refer to arrangements that result in either trade-offs or synergies. It is worth noting that in such bundles, the improvement of regulating ecosystem services generally correlates with the enhancement of provisioning and cultural ecosystem services $[102,104]$ and that negative trade-offs rarely occur between regulating ecosystem services [107]. Conversely, focus on the enhancement of provisioning ecosystem services (such as food production) generally correlates to the diminishing of regulating and cultural ecosystem services [104]. For example, external inputs utilised to increase provisioning ecosystem services (e.g., livestock or crop yield) decrease the flow of regulating services (e.g., pest control, pollination, water flow regulation, carbon storage) [8]. As will be developed further below, it is agroecological systems' capacity to provide bundles of ecosystem services synergies, based on a prioritisation of regulating ecosystem services and with the relative spatial economy, which underpins a new role for farming in periurban multiscapes. The context for this new role for farming is framed by two recent developments in ecosystem services. The first is the concept of Ecosystem Services Space (ES Space), and the second is the development of spatially explicit mapping of periurban ecosystem services supply and demand.

The concept of ES Space developed by Gomez-Creutzberg et al. (2021) involves hypothetically visualising the cumulative ecosystem services as supplied by all LULC within a given landscape [108]. Applying ordination analysis, it locates LULC that supply similar services closer to each other in ES Space than those that supply different services [108] (Figure 4). Their research concludes that there is an optimum balance between the amount of land cover heterogeneity and the spatial distribution of LULC providing ecosystem services. With too much heterogeneity, the loss or significant disruption of one of these LULC (along with its associated ecosystem services) degrades the overall resilience of the landscape. Conversely, a landscape comprising larger extents of land covers supplying complimentary multiple ecosystem services provides a high redundancy of these services, and hence, increased resilience [109]. Darnhofer et al. (2010) make explicit reference to agroecosystems' capacity to provide this redundancy and hence a buffering capacity to natural and human-made disturbances [110]. We propose that when utilised in coordination with landscape metrics, ES Space could potentially guide the proportionality of land covers to generate specific ecosystem service redundancy and, therefore, optimum resilience [111]. 


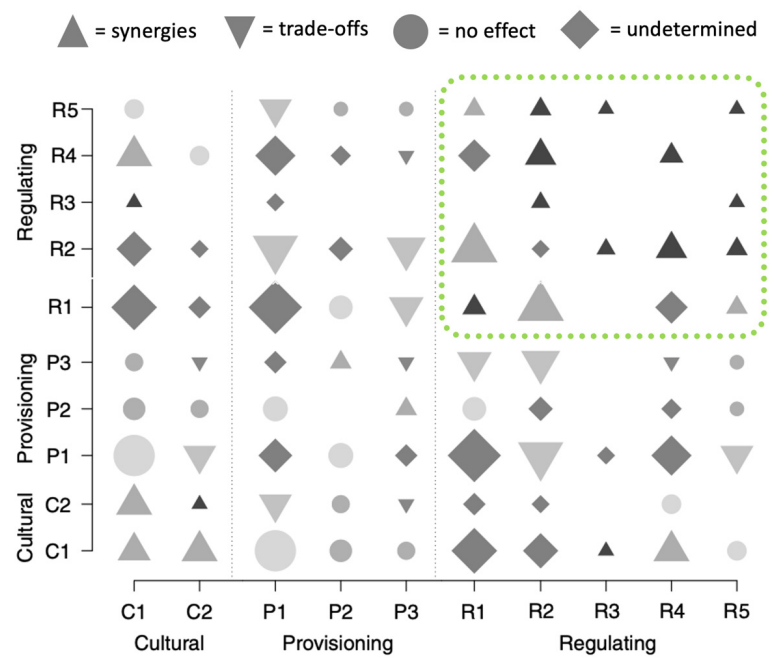

Figure 3. ES trade-off analysis from 67 case studies, showing the empirical pattern of relationships between them. The size of the symbol indicates the square root-scaled number of studies. Of note are the prevalent synergies between regulating ecosystem services. $\mathrm{C} 1$ : Physical and experiential interactions. C2: Intellectual and representative interactions. P1: Nutrition biomass. P2: Nutrition water (i.e., drinking purpose). P3: Materials biomass (e.g., for production and agricultural uses). R1: Atmospheric composition and climate regulation. R2: Life cycle maintenance, habitat and gene pool protection. R3: Pest and disease control. R4: Soil formation and composition. R5: Water filtration. Adapted from Lee, H. and Lautenbach, S. (2016). A quantitative review of relationships between ecosystem services. Ecological indicators, 66, 340-351.

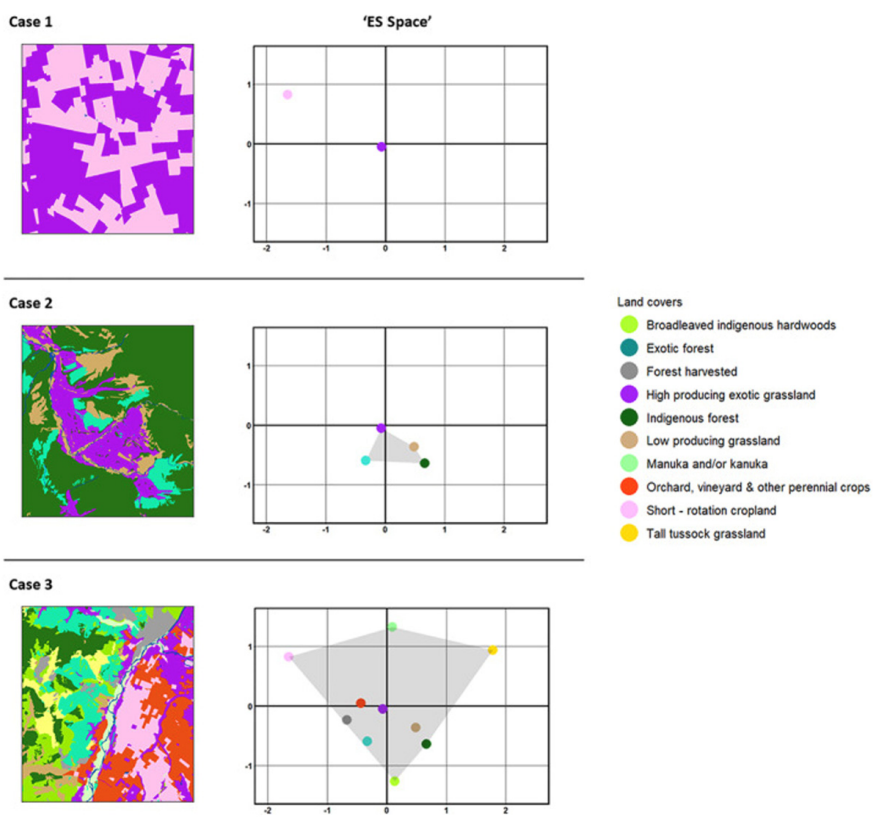

Figure 4. Hypothetical visualisations that explore trade-offs in the supply of multiple ecosystem services depending on the level of LULC heterogeneity across entire landscapes. $\bullet$ Case 1-a landscape with few, undifferentiated production land covers. • Case 2-a landscape with a medium combination of land covers. $\bullet$ Case 3-a landscape with a broad range of land covers that supply a diverse range of services. LULC mapping (left) is translated to ordination graphs (right), indicating a complementarity of ecosystem services supply bunched together and contrasting sets of ecosystem services set far apart. Complementarity equates to the redundancy of ecosystem services supply and, therefore, resilience. From Gómez-Creutzberg, C et al. (2021). Consistent trade-offs in ecosystem services between land covers with different production intensities. Biological reviews of the Cambridge Philosophical Society, 96(5). 
Emerging in the late 1990s with the development of Geographic Information Systems (GIS) [112], ecosystem services mapping has recently begun to shift from identifying only areas of ecosystem services supply (as applied in the ES Space concept), to matching ecosystem services supply with ecosystem services demand $[91,113,114]$. Cortinovis and Geneletti (2020) utilise ecosystem services supply and demand mapping to inform a performancebased planning strategy for periurban multiscapes [115]. The type of performance (i.e., what ecosystem services should be provided) depends on ecosystem service demand, which also dictates the quantity of ecosystem services to be supplied [116,117]. Additional supply is also needed to replenish ecosystem service sources depleted by urban expansion and conventional agricultural production pressures, for example, by increased soil sealing, diminished canopy coverage, fragmentation of valuable habitats and contamination of natural resources $[115,118,119]$.

Cortinovis and Geneletti demonstrate their supply and demand process with a 'combined ecosystem services supply map' (Figure 5) and an 'integrated ecosystem services demand map' [115] (Figure 6). As well as the periurban context of their research, the explicit delineation of respective sources and sinks of ecosystem services is of clear relevance to the spatial application of agroecology. For example, cluster analysis is used to map specific ecosystem service requirements to explicit locations, thus representing ES demand in a more explicit way than simply referring to population density maps [115]. The supplied ecosystem services assessed (as well as their indicators and calculation method) are set out in Table 1.

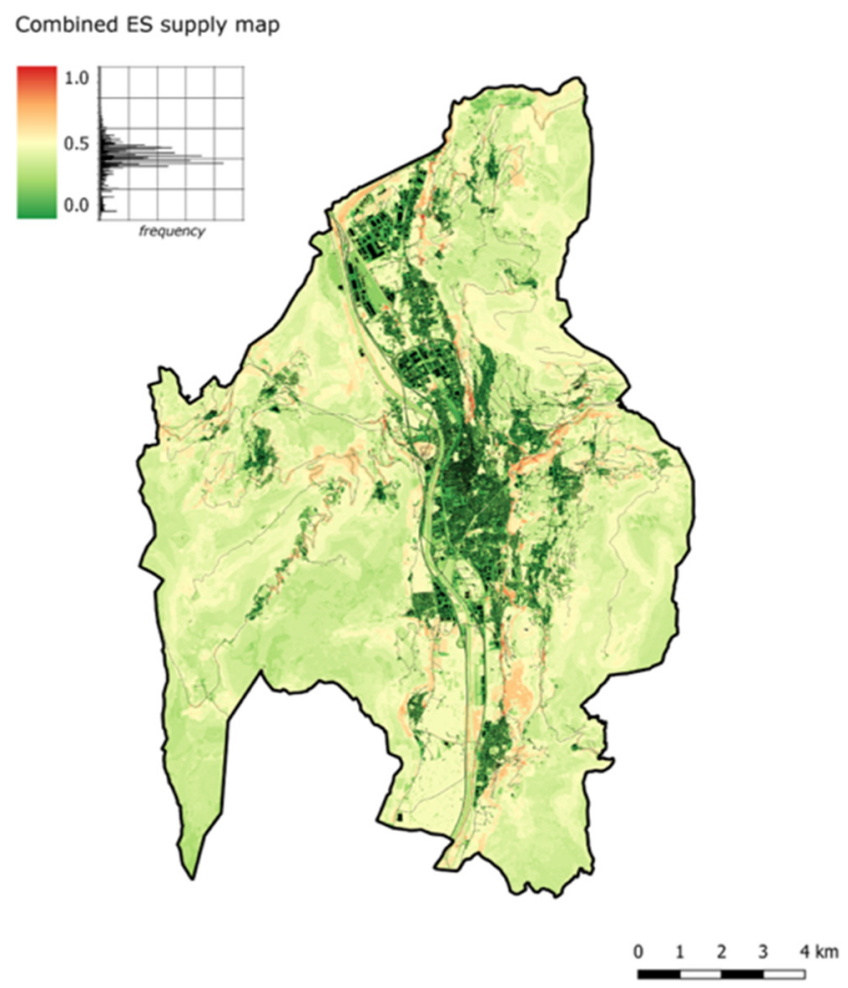

Figure 5. The 'combined ES supply' map summarises the results of the seven individual assessments of ES supply. In the centre of the map is a major town, set in a valley. Urbanised areas with little or no vegetation are clearly visible on the map as characterised by the lowest values of the indicator (in dark green). The map indicates highlights that the critical supply areas (in red) are located in the periurban zones branching out from the centre. These correspond to urban parks, protected areas and remnants of forests. From Cortinovis, C. and Geneletti, D., A Performance-based Planning Approach Integrating Supply and Demand of Urban Ecosystem Services. Lands. Urban Plan., 2020. 201: p. 103842. 


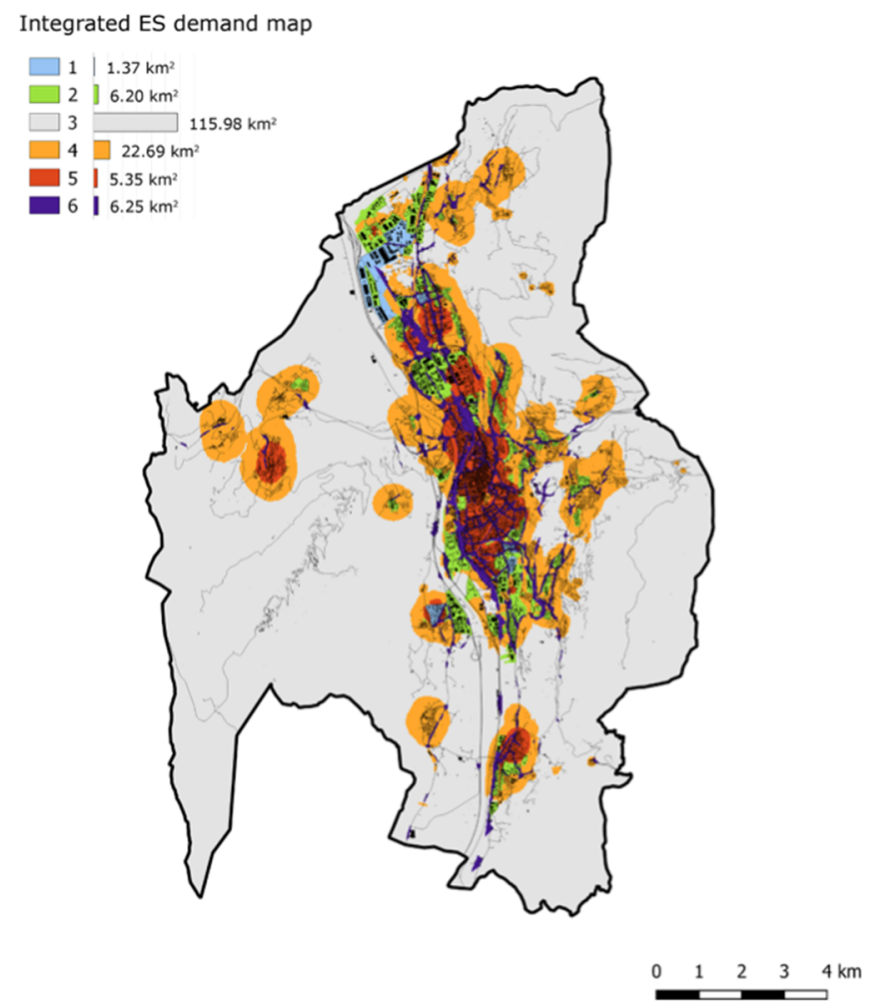

Figure 6. The 'integrated ES demand' map indicates six clusters characterised by similar ecosystem service demand profiles. Individual demand maps were informed by two factors: (1) the intensity of hazard (in the case of regulating services) or level of deprivation (in the case of provisioning and cultural services) and (2) the amount of population exposed to that condition, and consideration of different vulnerability levels. The characteristic requirements of each cluster are as follows: 1. High demand for runoff mitigation-mainly industrial or high-density residential areas with a high degree of soil sealing. 2. Relatively high demand for runoff mitigation and above-average demand for microclimate regulation, food supply and recreation-mainly residential areas with low levels of green space. 3. Non-urbanised areas, so very-low or no demand for the analysed ES. 4. Periurban areas - mostly non-urbanised areas or low-density residential neighbourhoods. These are characterised by a higher-than-average demand for microclimate regulation, recreation and food supply. 5. Main residential areas with a medium to high density, which have the highest demand for microclimate regulation, recreation, and food production. 6 . Noise regulation specifically required by residential areas close to transport infrastructure. From Cortinovis, C. and Geneletti, D., A Performance-based Planning Approach Integrating Supply and Demand of Urban Ecosystem Services. Lands. Urban Plan., 2020. 201: p. 103842.

Table 1. Ecosystem services assessed in Cortinovis and Geneletti (2020), including indicators and calculation methods [115].

\begin{tabular}{|c|c|c|}
\hline Ecosystem Services & Indicators & Calculation Method \\
\hline Microclimate regulation (cooling) & Cooling capacity of green infrastructure & Spatial modelling \\
\hline Habitat provision & Relative richness of focal species & Ecological modelling \\
\hline Nature-based recreation & Recreation Opportunity Spectrum & Spatial modelling \\
\hline Noise mitigation & $\begin{array}{l}\text { Reduction of traffic noise at selected } \\
\text { receivers (residential buildings) }\end{array}$ & Spatial modelling \\
\hline Air purification & PM10 deposition & $\begin{array}{c}\text { Proxy based on vegetation typology and } \\
\text { distance from main sources }\end{array}$ \\
\hline Runoff mitigation & Runoff avoided due to infiltration & Proxy based on the share of permeable areas \\
\hline Food provision & Land suitability for agriculture & $\begin{array}{l}\text { Proxy based on current crop typology and } \\
\text { suitability to agricultural use }\end{array}$ \\
\hline
\end{tabular}


Using spatial ecological modelling and the use of proxy LULC geometries, individual supply maps indicate the areas generating ecosystem services required by the urban area being studied $[120,121]$. The ecosystem services assessed are first illustrated on their own individual maps, with map pixels colour coded by a scale ranging from 0 to 1 indicating how much of the respective service they supply. To create the combined ecosystem services supply map, the individual maps are overlaid, their respective services summed and rescaled again to a $0-1$ range.

We mentioned earlier the sub-optimality of mapping LULC in only two dimensions. For example, Zhou et al. (2017) discuss the limitations of applying analogue (ecology in the city) LULC approaches to the mapping of hybrid human-natural (ecology of the city) systems [51] and Inostroza et al. (2019) highlight the constraints of applying twodimensional metrics to the analysis of the tetra-dimensional (three spatial dimensions plus time) periurban zone [50]. Nevertheless, two-dimensional supply/demand mapping provides useful data when the grain and extent of the mapping are aligned with the desired scale required by the analysis [1]. Cortinovis and Geneletti do draw attention to the practical limitations of scaling ecosystem service supply and demand values to a common range [115]. However, their study provides a framework to assess, in a spatially explicit manner, the location, quantity and type of ecosystem service supply and demand for a real-world periurban multiscape.

If such quantitative correlations between different LULCs and the supply of different ecosystem services can be established (as suggested by Laca, above), we suggest that ES Space theory could be used to compare how different spatial configurations of LULC deliver various services (Figure 1c). Gomez-Creutzberg et al. contend that no single land cover is a jack-of-all-trades, providing an optimal level of all ecosystem services [122]. As will be set out in the next section, we suggest agroecology because it consists of a functional arrangement of multiple land uses and landcovers within the same discrete spatial area, classified as a separate LULC class. We further suggest that spatial agroecology-the spatial configuration of these spatially discrete agroecological units (as well as modulations of farm operations occurring within these components) — can perform an ecosystemic jack-of-all trades role supplying ecosystem services tailored to what is required and with a high degree of spatial efficiency.

\section{Agroecology}

Agroecology is described as a science, a social movement and a set of agricultural practices [123]. While the social movement and agricultural practice components have a significant role to play in urban-rural reconciliation, they are beyond the scope of this review. Instead, we focus here on agroecology, as defined by Gleissman (2007), as the science of applying ecological concepts and principles to the design and management of sustainable food systems [124]. Wezel et al. (2013) refine this definition to explicitly include ecosystem services: the objectives of agroecology are to produce significant amounts of food while 'valorising ecological processes and ecosystem services' by integrating them as fundamental elements of farming operations [125]. An important differentiator of agroecology from other varieties of 'sustainable' agriculture is a scientific and operational commitment to structural change. Duru et al. (2015) describe agroecology as taking a systemic and holistic view of agricultural systems, compared to the efficiency and/or substitution paradigm behind most 'sustainable' improvements to monocultural agriculture [126]. Examples of this deeper, structural re-design approach are manifest throughout agroecological practices: from cultivar or livestock choice and pest management, through the hegemonic weighting applied to soil health, to the functional integration of semi-natural landscape elements, such as dams, windbreaks and terraces [127]. The result is that agroecological systems are based on a more complex and heterogeneous ecological foundation than conventional agricultural systems. Subsequently, they possess a greater capacity for self-organisation and adaptation to higher levels of uncertainty $[126,128]$. 
These traits, which are integral to the quality of ES Plasticity, are in turn derived from agroecology's fundamental concern with diversity. This systemic diversity does not occur naturally but is the result of iterative farm design, continuous monitoring and purposeful management practices $[129,130]$. Diversity is a prevalent trait across all principles of agroecology, from biological to operational [131,132]. For example, Table 2 illustrates principles for grass-based farming systems listed by Peeters and Wezel [133].

Table 2. Agroecological Principles for Grass-based Farming Systems.

\section{Land and resource management:}

- Diversification of land-use/land cover/livestock types and productions

- Mixed cropping/livestock systems

- Biodiversity conservation

Technical production aspects:

- Grassland and rangeland health (favouring complex, species-rich swards, combined with rotational grazing)

- $\quad$ Livestock types (species diversity not discussed, but dietary diversity is noted as fundamental to animal welfare and product quality)

\section{Socioeconomic aspects:}

- Diversification of income streams

- Optimisation of farming and food systems (emphasis on shorter value chains results in multiple supply options instead of conventional single stream industrial food value chains)

Expanding further on Wezel's' definition, in particular, the valorisation of multiple ecosystem services, a meta-analysis of research on the topic confirms that agroecological systems are characterised by more synergies across all types of ecosystem servicesprovisioning, regulating and cultural—compared with other farming systems [134]. For example, ecological processes and functions (e.g., predation, flower visits, mineralisation), allow the provision of regulating services (e.g., pest control, pollination, nutrient cycling), on which provisioning (production of biomass for food, fibre and energy) and cultural services (e.g., landscape visual amenity, recreation resources) depend [135]. The stacking of multiple ecosystem services in agroecological systems is shown to result in substantially greater biodiversity, soil quality, carbon sequestration, water retention, energy-use efficiency and resilience to climate change, in comparison to conventional, productionfocused, high-input agriculture $[19,128]$. As noted earlier, this density of agroecological regulating ecosystem services (such as flood protection, waste decomposition, nutrient cycling, pest control and crop pollination), underpins the final benefits of provisioning and cultural ecosystem services [18,136]. In such agroecological systems, the economic value of these regulating services has been shown to exceed the value of the final provisioning services [136]. Therefore, while both the Wezel and Gleissman definitions of agroecology centralise food production, an emerging emphasis is being placed on agroecology's spatial multifunctionality, which emphasises the significant benefits to regional and global environments of agroecological regulating ecosystem services [137-139]. Spake et al. (2017) point out that the understanding of the multiplication of ecosystem services from the same area, or ES Density, is in its infancy [140]. While landscape patterns of this multifunctionality are mappable, the processes underlying them are not yet clear, and neither are the implications of moving between various scales, such as between paddock, farm or multiscape [140].

We can compare the potential multifunctional role of periurban agroecosystems to Urban Green Infrastructure (UGI), which is the focus of most recent research into urban ecosystem services [141]. UGI comprises planned networks of parks and gardens, urban forests, green roofs and facades and waterways to deliver multiple ecosystem services [142,143], including biodiversity conservation, air purification, urban temperature regulation, storm-water mitigation, noise reduction and recreation [26,113]. Rolf et al. (2020) have suggested that periurban agriculture could also provide such ecosystem services, on top of contributing to urban nutritional security [142]. Two significant factors, however, 
elevate periurban agroecosystems above the descriptor 'edible green infrastructure' [142] in terms of its potential impact on sustainable periurbanisation.

The first consideration is the scale of periurban agroecosystems compared to the residual nature of land conventionally occupied by UGI within urban contexts. Examples include the utilisation of vacant land caused by economic downturn or natural disaster or by linking already existing green infrastructure, such as parks and nature reserves. As UGI evolves from this residual status to designation as 'a backbone for structuring urban development over large surfaces' [144], its ecosystemic impact will likewise increase. However, in the context of the periurban continuum, the surfaces comprising agroecosystems are likely to be significantly larger again. The potential impact of agroecological systems being re-operationalised to enhance regulating ecosystem services is the subject of recent discussion [145-149]. Dominati et al. (2019) conclude that when the extent of agroecosystems (for example, approximately $40 \%$ of land area in NZ, $45 \%$ in the USA and $70 \%$ in the UK) is taken into account, there is enormous scope for the impact of agroecology on ecosystem service supply at the landscape scale [146]. This echoes Tittonell (in the context of global biodiversity conservation), who notes that the area of nature reserves represents less than $5 \%$ of the terrestrial surface area of the globe, and therefore, the onus for remediation falls on production landscapes, representing over 30\% of the Earth's land area [150].

The second consideration is the constant human agency (i.e., iterative farm design, continuous monitoring and purposeful management practices) that is absent from UGI and which underpins agroecological practice and its capacity to provide ES Plasticity. Notably, this includes being able to respond to specific ecosystems service demand, whereas UGI only addresses ecosystem service supply [115]. The term ecosystem service plasticity has been used to describe the ability of a natural system to incorporate human and natural stressors without loss of ecological function [78]. In this periurban context, however, we propose using the term ES Plasticity to express agroecosystems' capability to manipulate the mix and quantity of supplied ecosystem services to create synaptic relationships with the specific ecosystem services required by that multiscape $[146,148,151]$. By diversifying agricultural operations spatially and temporally, LULC can be adjusted to render specific ES in response to identified ES demand. Referring to Figure 6., the integrated ES Demand map identifies specific ES demanded by specific locations in the research landscape. Following the hypothesis, we are proposing agroecological systems that are the periurban sources of ES, such as those identified in the Combined Supply Map (Figure 5), can be adjusted to meet these specific demands.

The diagram developed throughout this review is, at this point, a circle nearing closure (Figure 1d). The final quadrant connects agroecology back to ecological urbanism, and specifically, ecology for the city. Ecology for the city is very much focussed on future trajectories [59]; similarly, the diagram implies that the completion of the circle depends first on spatial agroecology accomplishing spatially optimum configurations, as previously projected in the convergence of landscape ecology, ecosystem services science and agroecology. Recalling the tenet of ecology for the city, which suggests the unprecedented pace of urbanisation will accelerate rates of co-evolution perhaps crossing these positive thresholds will be achieved sooner than expected [59].

Moreover, the promising of an eventual 'design-ecology nexus' of agroecology and ecology for the city is their lingua franca of adaptative complexity. The ecologically complex, intensive systems that agroecology generates are a counterpoint to the artificial simplicity engendered by production-oriented monocultural agricultural practices [18,131]. Vandermeer and Perfecto (2017) recommend applying concepts of ecological complexity, such as chaotic dynamics, stochastic processes and critical transitions, to help identify simple rules behind the complex patterns in agroecological systems [152]. Darnhofer et al. (2010) and Tittonell (2014) also develop the theme of complexity and risk inherent in agroecological systems by transposing the cyclical process of agroecological resilience to Gunderson and Holling's well-known diagram of complex adaptive systems [110,128,153] (Figure 7). The same model has been applied in ecological urbanism to trace the evolution of the field 
since the 1950s through the complex adaptive phases of growth, equilibrium, collapse and reorganisation $[59,154]$, from steady-state (ecology in the city), through multiple equilibria (ecology of the city) to co-evolution (ecology for the city) [59]. It is in this latter future transitional phase where the greatest similarities to agroecology occur, asserting that maximum flexibility (ES Plasticity) is required to adapt to uncertain future conditions [59]. From this reorganisation emerges potential new ecological patterns, processes and functions from coupled human-natural systems, such as agroecological systems, with positive implications for ecological and human well-being.

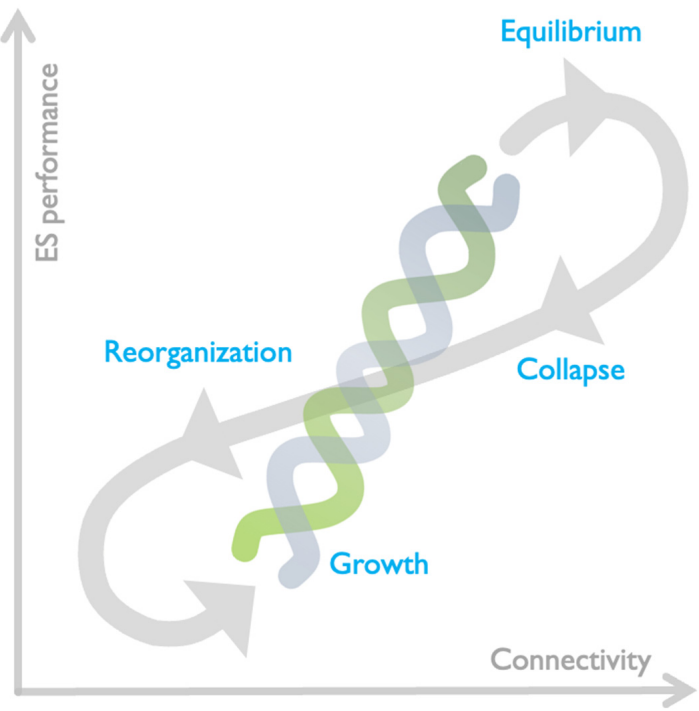

Figure 7. The complex adaptive cycle proposed by Gunderson and Holling (2002) that describes ecosystem dynamics considering four stages: growth, equilibrium, which are the two main phases of succession, followed by the phases of collapse and reorganisation. Adapted from Burkhard, B., et al., (2011). Adapting the Adaptive Cycle: Hypotheses on the Development of Ecosystem Properties and Services. Eco. Mod., 222(16).

\section{Conclusions}

This paper identifies urbanisation as an additional factor to be considered in multiscapes; in doing so, it makes the case for a different way of considering farming. Instead of regarding multiscapes as mainly productive landscapes interspersed with ancillary human settlements, the reality is that continually evolving multiscapes will need to contend with the growing interspersion of urbanisation.

The new role for farming in this changing context fundamentally derives from Wezel's identification of agroecology as a land-use that equally valorises regulating, cultural and provisioning ecosystem services. This holistic ecosystemic approach underpins agroecology's ES Density and ES Plasticity—spatial properties specifically suited to providing critical periurban ecosystem services as more periurban space is converted to what are conventionally considered urban uses. These spatial properties are the basis of a new synthesis of four fields of research-ecological urbanism, landscape ecology, ecosystem services science and agroecology - that converge on the periurban zone. For instance, by recognising agroecology's ecosystemic potential beyond food production, the application of metrics developed in landscape ecology may lead to new understandings of landscape configuration and ecosystem service performance. These landscape metrics might follow the conventional discretised patch-mosaic format as a starting point while investigating alternative methods (such as fractals and surface metrics) potentially more suited to the continuum of periurban multiscapes. Complementary to this line of research, ongoing advances in ecosystem services science are allowing clearer mapping and quantification of periurban ecosystem service supply and demand. As represented by the conceptual model diagrammed in this review, the design of agroecological farm systems, based on 
ES Density and ES Plasticity, synthesise with landscape ecology and ecosystem services sciences to supply specific qualities and quantities of ecosystem services at various scaleswithin the farm, as aggregations of farms or at the multiscape scale. The final quadrant of the diagram comprises the interface between agroecology and ecological urbanism, connected by a lingua franca of adaptative complexity. This nexus, which epitomises the periurban continuum between urban and rural, beckons future research. Up to this point, the direction of ecosystem services flow has essentially been from outer to inner, from rural to urban. As spatial agroecology sees agriculture becoming an integral component of coupled human-natural urbanisation, it follows that ecosystem services will eventually also be designed to flow reciprocally from inner to outer, with urban metabolic processes contributing to the ecosystemic demands of agroecological systems. This would augment the notion of reconciliation of periurban multiscapes by spatial agroecology. In addition to agroecological farming systems providing ecosystem-based actions to offset the negative impacts generated by the urbanisation, the design-nexus of ecological urbanism and agroecology would see urbanisation positively contributing to agroecology.

Limitations to the conceptual approach proposed in this review include the suboptimal reliance on static LULC classifications that represents the loss of internal heterogeneity within patches. Developing alternatives to the patch-mosaic paradigm is a central concern for landscape ecology. However, this two-dimensional paradigm is a necessary tactic in developing the conceptual synthesis of agroecology, landscape ecology and ecosystem services science proposed here. Two other limitations are (1) the availability of suitable land for agroecology in the rapidly transforming periurban zone and (2) the governance structures required to disseminate, orchestrate and regulate spatial agroecology. In response to the first point, the possible scarcity of land capable of supporting the ecosystem provides the urgent impetus to uncover correlations between the configuration and ecosystem services performance, so that what little is saved from irreversible damage can be utilised in the most spatially optimal means possible. The second issue, the governance required to implement spatial agroecology, is dependent on whether the ecosystem services approach will become widely accepted as the primary paradigm to engage with the systemic challenges of climate change, nutritional security, biodiversity loss and human health. As there is no way of foretelling this result, advancing the concept of spatial ecology must proceed on the basis that it will be deployed both prophylactically to head off potentially dire ecosystemic outcomes and therapeutically, as these dire outcomes become prevalent across periurban multiscapes.

Author Contributions: Conceptualisation, R.M.; writing—original draft preparation, R.M.; writingreview and editing, S.D., G.-A.G. and P.G.; visualisation, R.M. All authors have read and agreed to the published version of the manuscript.

Funding: R.M. is funded by a Food Transitions 2050 doctoral scholarship (Food Transitions 2050 Joint Postgraduate School, Faculty of Agriculture and Life Sciences, Lincoln University) and the APC was funded by the Lincoln University Open Access Publishing Fund.

Institutional Review Board Statement: Not applicable.

Informed Consent Statement: Not applicable.

Data Availability Statement: Not applicable.

Conflicts of Interest: The authors declare no conflict of interest.

\section{References}

1. Mastrangelo, M.E.; Weyland, F.; Villarino, S.H.; Barral, M.P.; Nahuelhual, L.; Laterra, P. Concepts and methods for landscape multifunctionality and a unifying framework based on ecosystem services. Landsc. Ecol. 2014, 29, 345-358. [CrossRef]

2. Gregorini, P.; Maxwell, T.M.R. Grazing in future multiscapes-From thoughtscapes to ethical and sustainable foodscapes. Journal 2020, 24, 23-25.

3. Seto, K.C.; Golden, J.S.; Alberti, M.; Turner, B.L. Sustainability in an urbanizing planet. Proc. Natl. Acad. Sci. USA 2017, 114, 8935-8938. [CrossRef] [PubMed] 
4. Grimm, N.B.; Faeth, S.H.; Golubiewski, N.E.; Redman, C.L.; Wu, J.; Bai, X.; Briggs, J.M. Global change and the ecology of cities. Science 2008, 319, 756-760. [CrossRef] [PubMed]

5. $\quad$ Fry, T. Remaking Cities: An Introduction to Urban Metrofitting; Bloomsbury Publishing Plc.: London, UK, 2017.

6. Tilman, D.; Fargione, J.; Wolff, B.; D’Antonio, C.; Dobson, A.; Howarth, R.; Schindler, D.; Schlesinger, W.H.; Simberloff, D.; Swackhamer, D. Forecasting agriculturally driven global environmental change. Science 2001, 292, 281-284. [CrossRef]

7. Vitousek, P.M.; Mooney, H.A.; Lubchenco, J.; Melillo, J.M. Human domination of earth's ecosystems. Science 1997, 277, 494-499. [CrossRef]

8. Foley, J.A.; Ramankutty, N.; Brauman, K.A.; Cassidy, E.S.; Gerber, J.S.; Johnston, M.; Mueller, N.D.; O'Connell, C.; Ray, D.K.; West, P.C.; et al. Solutions for a cultivated planet. Nature 2011, 478, 337-342. [CrossRef]

9. Kearnes, M.; Rickards, L. Knowing earth, knowing soil: Epistemological work and the political aesthetics of regenerative agriculture. In Thinking with Soils: Material Politics and Social Theory; Bloomsbury: London, UK, 2020; pp. 71-88.

10. Freemark, K. Farmlands for Farming and Nature; Cambridge University Press: Cambridge, UK, 2005; pp. $193-200$.

11. McPhearson, T.; Pickett, S.T.A.; Grimm, N.B.; Niemelä, J.; Alberti, M.; Elmqvist, T.; Weber, C.; Haase, D.; Breuste, J.; Qureshi, S. Advancing urban ecology toward a science of cities. Bioscience 2016, 66, 198-212. [CrossRef]

12. Salazar, G.; Jalabert, D. Towards a landscape ecosophy. Interpreting how the villarrica-pucón urban system inhabitants in the araucanía region of chile perceive and relate with the dynamics of landscape. SciELO J. 2018, 8, 28-41. [CrossRef]

13. Allen, A. Environmental planning and management of the peri-urban interface: Perspectives on an emerging field. Environ. Urban. 2003, 15, 135-148. [CrossRef]

14. Seto, K.; Parnell, S.; Elmqvist, T. A global outlook on urbanization. In Urbanization, Biodiversity and Ecosystem Services: Challenges and Opportunities; Springer: Dordrecht, The Netherlands, 2013; pp. 1-12.

15. Daily, G.C. Nature's Services: Societal Dependence on Natural Ecosystems; Island Press: Washington, DC, USA, 1997.

16. Colloff, M.J.; Wise, R.M.; Palomo, I.; Lavorel, S.; Pascual, U. Nature's contribution to adaptation: Insights from examples of the transformation of social-ecological systems. Ecosyst. People 2020, 16, 137-150. [CrossRef]

17. Costanza, R.; de Groot, R.; Braat, L.; Kubiszewski, I.; Fioramonti, L.; Sutton, P.; Farber, S.; Grasso, M. Twenty years of ecosystem services: How far have we come and how far do we still need to go? Ecosyst. Serv. 2017, 28, 1-16. [CrossRef]

18. Bommarco, R.; Kleijn, D.; Potts, S.G. Ecological intensification: Harnessing ecosystem services for food security. Trends Ecol. Evol. 2013, 28, 230-238. [CrossRef] [PubMed]

19. Rossing, W.A.H.; Modernel, P.; Tittonell, P.A. Diversity in Organic and Agroecological Farming Systems for Mitigation of Climate Change Impact, with Examples from Latin America. In Climate change impact and adaptation in agricultural systems; CABI: Wallingford, UK, 2014; pp. 69-87.

20. Cabel, J.F.; Oelofse, M. An indicator framework for assessing agroecosystem resilience. Ecol. Soc. 2012, 17, 18. [CrossRef]

21. Petersen-Rockney, M.; Baur, P.; Guzman, A.; Bender, S.F.; Calo, A.; Castillo, F.; De Master, K.; Dumont, A.; Esquivel, K.; Kremen, C.; et al. Narrow and brittle or broad and nimble? Comparing adaptive capacity in simplifying and diversifying farming systems. Front. Sustain. Food Syst. 2021, 5, 56. [CrossRef]

22. Capra, F. The Systems View of Life: A Unifying Vision; Cambridge University Press: Cambridge, UK, 2014.

23. D'Aoust, O.; Singh, G.; Cadavid, P.R.; Goga, S.; Terraza, H.; Lakovits, C.; Baeumler, A.; Gapihan, A. Demographic Trends and Urbanization; World Bank: Washington, DC, USA, 2021.

24. Jiang, L.; O'Neill, B.C. Global urbanization projections for the Shared Socioeconomic Pathways. Glob. Environ. Change 2017, 42, 193-199. [CrossRef]

25. Champion, A.G.; Hugo, G. New Forms of Urbanization: Beyond the Urban-Rural Dichotomy; Routledge: Oxon, UK, 2013.

26. Elmqvist, T.; Fragkias, M.; Goodness, J.; Güneralp, B.; Marcotullio, P.J.; McDonald, R.I.; Parnell, S.; Schewenius, M.; Sendstad, M.; Seto, K.C.; et al. (Eds.) Urbanization, Biodiversity and Ecosystem Services: Challenges and Opportunities: A Global Assessment; Springer Nature: London, UK, 2013.

27. Mahtta, R.; Mahendra, A.; Seto, K.C. Building up or spreading out? Typologies of urban growth across 478 cities of 1 million. Environ. Res. Lett. 2019, 14, 124077. [CrossRef]

28. Ortiz-Báez, P.; Cabrera-Barona, P.; Bogaert, J. Characterizing landscape patterns in urban-rural interfaces. J. Urban Manag. 2021, 10, 46-56. [CrossRef]

29. Batty, M. The New Science of Cities; MIT Press: Cambridge, MA, USA, 2013.

30. UN. The Sustainable Development Goals Report; United Nations Publications: New York, NY, USA, 2021.

31. Inostroza, L.; Baur, R.; Csaplovics, E. Urban sprawl and fragmentation in Latin America: A dynamic quantification and characterization of spatial patterns. J. Environ. Manag. 2013, 115, 87-97. [CrossRef]

32. Brown, L.R. Eco-Economy: Building an Economy for the Earth, 1st ed.; W.W. Norton: New York, NY, USA, 2001.

33. Gao, J.; O'Neill, B.C. Mapping global urban land for the 21st century with data-driven simulations and Shared Socioeconomic Pathways. Nat. Commun. 2020, 11, 2302. [CrossRef]

34. Geneletti, D.; La Rosa, D.; Spyra, M.; Cortinovis, C. A review of approaches and challenges for sustainable planning in urban peripheries. Landsc. Urban Plan. 2017, 165, 231-243. [CrossRef]

35. Scott, J.C. Against the Grain: A Deep History of the Earliest States; Yale University Press: New Haven, CT, USA, 2017.

36. Thebo, A.L.; Drechsel, P.; Lambin, E.F. Global assessment of urban and peri-urban agriculture: Irrigated and rainfed croplands. Environ. Res. Lett. 2014, 9, 114002. [CrossRef] 
37. Haller, A. Urbanites, smallholders, and the quest for empathy: Prospects for collaborative planning in the periurban Shullcas Valley, Peru. Landsc. Urban Plan. 2017, 165, 220-230. [CrossRef]

38. Curran-Cournane, F.; Vaughan, M.; Memon, A.; Fredrickson, C. Trade-offs between high class land and development: Recent and future pressures on Auckland's valuable soil resources. Land Use Policy 2014, 39, 146-154. [CrossRef]

39. Tóth, G. Impact of land-take on the land resource base for crop production in the European Union. Sci. Total Environ. 2012, 435-436, 202-214. [CrossRef]

40. Godfray, H.C.J.; Beddington, J.R.; Crute, I.R.; Haddad, L.; Lawrence, D.; Muir, J.F.; Pretty, J.; Robinson, S.; Thomas, S.M.; Toulmin, C. Food security: The challenge of feeding 9 billion people. Science 2010, 327, 812-818. [CrossRef]

41. Bren d'Amour, C.; Reitsma, F.; Baiocchi, G.; Barthel, S.; Güneralp, B.; Erb, K.-H.; Haberl, H.; Creutzig, F.; Seto, K.C. Future urban land expansion and implications for global croplands. Proc. Natl. Acad. Sci. USA 2017, 114, 8939-8944. [CrossRef]

42. McHale, M.; Pickett, S.; Barbosa, O.; Bunn, D.; Cadenasso, M.; Childers, D.; Gartin, M.; Hess, G.; Iwaniec, D.; McPhearson, T.; et al. The new global urban realm: Complex, connected, diffuse, and diverse social-ecological systems. Sustainability 2015, 7, 5211-5240. [CrossRef]

43. Metzger, M.J.; Rounsevell, M.D.A.; Acosta-Michlik, L.; Leemans, R.; Schröter, D. The vulnerability of ecosystem services to land use change. Agric. Ecosyst. Environ. 2006, 114, 69-85. [CrossRef]

44. UNHS Programs. State of the World's Cities 2008/2009: Harmonious Cities; UN: London, UK, 2008.

45. Boone, C.G.; Redman, C.L.; Blanco, H.; Haase, D.; Koch, J.; Lwasa, S.; Nagendra, H.; Pauleit, S.; Pickett, S.T.A.; Seto, K.C.; et al. Reconceptualizing Land for Sustainable Urbanity; MIT Press: Cambridge, MA, USA, 2014; pp. 313-330.

46. Seto, K.C.; Reenberg, A.; Lupp, J. Rethinking Global Land Use in an Urban Era; The MIT Press: Cambridge, MA, USA, 2014.

47. Bogunovich, D. From planning sustainable cities to designing resilient urban regions. WIT Trans. Ecol. Environ. 2009, 120, 87-96.

48. Viljoen, A.; Schlesinger, J.; Bohn, K.; Drescher, A. Agriculture in urban design and spatial planning. In Cities and Agriculture: Developing Resilient Urban Food Systems; Routledge: London, UK, 2015; pp. 88-120.

49. Pickett, S.T.A.; Zhou, W. Global urbanization as a shifting context for applying ecological science toward the sustainable city. Ecosyst. Health Sustain. 2015, 1, 1-15. [CrossRef]

50. Inostroza, L.; Hamstead, Z.; Spyra, M.; Qureshi, S. Beyond urban-rural dichotomies: Measuring urbanisation degrees in central European landscapes using the technomass as an explicit indicator. Ecol. Indic. 2019, 96, 466-476. [CrossRef]

51. Zhou, W.; Pickett, S.T.A.; Cadenasso, M.L. Shifting concepts of urban spatial heterogeneity and their implications for sustainability. Landsc. Ecol. 2017, 32, 15-30. [CrossRef]

52. Cadenasso, M.L.; Pickett, S.T.A. Urban principles for ecological landscape design and management: Scientific fundamentals. Cities Environ. 2008, 1, 1-16. [CrossRef]

53. Rosales, N. How can an ecological perspective be used to enrich cities planning and management? Urbe. Rev. Bras. De Gestão Urbana 2017, 9, 314-326. [CrossRef]

54. Spirn, A.W. Ecological Urbanism: A Framework for the Design of Resilient Cities; Island Press/Center for Resource Economics: Washington, DC, USA, 2014; pp. 557-571.

55. Thomson, G.; Newman, P. Green infrastructure and biophilic urbanism as tools for integrating resource efficient and ecological cities. Urban Plan. 2021, 6, 75-88. [CrossRef]

56. Pickett, S.T.A.; Cadenasso, M.L.; Childers, D.L.; McDonnell, M.J.; Zhou, W. Evolution and future of urban ecological science: Ecology in, of, and for the city. Ecosyst. Health Sustain. 2016, 2, e01229. [CrossRef]

57. Kirchhoff, T.; Trepl, L.; Vicenzotti, V. What is Landscape Ecology? An Analysis and Evaluation of Six Different Conceptions. Landsc. Res. 2013, 38, 33-51. [CrossRef]

58. Schiere, J.; Groenland, R.; Vlug, A.; Van Keulen, H. System thinking in agriculture: An overview. In Emerging Challenges for Farming Systems: Lessons from Australian and Dutch Agriculture; Rural Industries Research and Development Corporation: Barton, Australia, 2004.

59. Alberti, M. Cities that Think Like Planets: Complexity, Resilience, and Innovation in Hybrid Ecosystems; University of Washington Press: Seattle, WA, USA, 2016.

60. Wu, J.; Loucks, O.L. From balance of nature to hierarchical patch dynamics: A paradigm shift in ecology. Q. Rev. Biol. 1995, 70, 439-466. [CrossRef]

61. Vetter, S. Rangelands at equilibrium and non-equilibrium: Recent developments in the debate. J. Arid. Environ. 2005, 62, 321-341. [CrossRef]

62. Pickett, S.T.A.; Burch, W.R., Jr.; Dalton, S.E.; Foresman, T.W. Integrated urban ecosystem research. Urban Ecosyst. 1997, 1, 183-184. [CrossRef]

63. Gandy, M. From urban ecology to ecological urbanism: An ambiguous trajectory: From urban ecology to ecological urbanism. Area 2015, 47, 150-154. [CrossRef]

64. Grimm, N.B.; Grove, J.G.; Pickett, S.T.A.; Redman, C.L. Integrated Approaches to Long-Term Studies of Urban Ecological Systems. BioScience 2000, 50, 571-584. [CrossRef]

65. Pickett, S.T.A.; Cadenasso, M.L.; Rosi-Marshall, E.J.; Belt, K.T.; Groffman, P.M.; Grove, J.M.; Irwin, E.G.; Kaushal, S.S.; LaDeau, S.L.; Nilon, C.H.; et al. Dynamic heterogeneity: A framework to promote ecological integration and hypothesis generation in urban systems. Urban Ecosyst. 2016, 20, 1-14. [CrossRef] 
66. Cadenasso, M.L.; Pickett, S.T.A.; Schwarz, K. Spatial heterogeneity in urban ecosystems: Reconceptualizing land cover and a framework for classification. Front. Ecol. Environ. 2007, 5, 80-88. [CrossRef]

67. Alberti, M.; Marzluff, J.M.; Shulenberger, E.; Bradley, G.; Ryan, C.; Zumbrunnen, C. Integrating humans into ecology: Opportunities and challenges for studying urban ecosystems. BioScience 2003, 53, 1169-1179. [CrossRef]

68. Childers, D.; Cadenasso, M.; Grove, J.; Marshall, V.; McGrath, B.; Pickett, S. An Ecology for Cities: A Transformational nexus of design and ecology to advance climate change resilience and urban sustainability. Sustainability 2015, 7, 3774-3791. [CrossRef]

69. Alberti, M.; Marzluff, J.M. Ecological resilience in urban ecosystems: Linking urban patterns to human and ecological functions. Urban Ecosyst. 2004, 7, 241-265. [CrossRef]

70. Turner, M.G. Landscape ecology: The effect of pattern on process. Annu. Rev. Ecol. Syst. 1989, 20, 171-197. [CrossRef]

71. Forman, R.T.T. Land Mosaics: The Ecology of Landscapes and Regions; Cambridge University Press: New York, NY, USA, 1995.

72. Troll, C. The geographic landscape and its investigation. In Foundation Papers in Landscape Ecology; Wiens, J.A., Moss, M.R., Turner, M.G., Mladenoff, D.J., Eds.; Columbia University Press: New York, NY, USA, 2007; pp. 71-101.

73. Farina, A. Ecosemiotic Landscape: A Novel Perspective for the Toolbox of Environmental Humanities; Cambridge University Press: Cambridge, UK, 2021.

74. Turner, M.G.; Gardner, R.H. Landscape Ecology in Theory and Practice: Pattern and Process; Springer: New York, NY, USA, 2015.

75. McGarigal, K.; Tagil, S.; Cushman, S.A. Surface metrics: An alternative to patch metrics for the quantification of landscape structure. Landsc. Ecol. 2009, 24, 433-450. [CrossRef]

76. Wiens, J.A. Landscape mosaics and ecological theory. In Mosaic Landscapes and Ecological Processes; Hansson, L., Fahrig, L., Merriam, G., Eds.; Springer: Dordrecht, The Netherlands, 1995; pp. 1-26.

77. Uuemaa, E.; Mander, Ü.; Marja, R. Trends in the use of landscape spatial metrics as landscape indicators: A review. Ecol. Indic. 2013, 28, 100-106. [CrossRef]

78. Farina, A. Human Stewardship in Ecological Mosaics: Linking People to Landscape Dynamics. In Landscape Ecology and Resource Management: Linking Theory with Practice; Bissonette, J.A., Storch, I., Eds.; Island Press: Washington, DC, USA, 2003 ; pp. 177-192.

79. Palmer, M.; Bernhardt, E.; Chornesky, E.; Collins, S.; Dobson, A.; Duke, C.; Gold, B.; Jacobson, R.; Kingsland, S.; Kranz, R.; et al. Ecology for a Crowded Planet. Science 2004, 304, 1251-1252. [CrossRef]

80. Farina, A. Principles and Methods in Landscape Ecology: Toward a Science of Landscape, 2nd ed.; Springer: Dordrecht, The Netherlands, 2006.

81. Crossman, N.; Burkhard, B.; Nedkov, S.; Willemen, L.L.J.; Petz, K.; Palomo, I.; Kou, E.G.; Martín-Lopez, B.; McPhearson, T.; Boyanova, K.; et al. A blueprint for mapping and modelling ecosystem services. Ecosyst. Serv. 2013, 4, 4-14. [CrossRef]

82. Mitchell, M.G.E.; Chan, K.M.A.; Newlands, N.K.; Ramankutty, N. Spatial correlations don't predict changes in agricultural ecosystem services: A canada-wide case study. Front. Sustain. Food Syst. 2020, 4, 1-17. [CrossRef]

83. Wu, J. Scale and Scaling: A Cross-Disciplinary Perspective; Cambridge University Press: Cambridge, UK, 2007 ; pp. 115-142.

84. Pickett, S.T.A.; Cadenasso, M.L. Landscape ecology: Spatial heterogeneity in ecological systems. Science 1995, 269, 331-334. [CrossRef]

85. Pickett, S.T.A.; Wu, J.; Cadenasso, M.L. Patch Dynamics and the Ecology of Disturbed Ground: A Framework for Synthesis; Elsevier: Amsterdam, The Netherlands, 1999.

86. Wu, J.; Jelinski, D.E.; Luck, M.; Tueller, P.T. Multiscale analysis of landscape heterogeneity: Scale variance and pattern metrics. Geogr. Inf. Sci. 2000, 6, 6-19. [CrossRef] [PubMed]

87. Wu, J.; Jones, K.; Li, H.-T.; Loucks, O. Scaling and Uncertainty Analysis in Ecology: Methods and Applications; Springer: Dordrecht, The Netherlands, 2006.

88. Wiens, J.A.; Milne, B.T. Scaling of 'landscapes' in landscape ecology, or, landscape ecology from a beetle's perspective. Landsc. Ecol. 1989, 3, 87-96. [CrossRef]

89. McGarigal, K.; Cushman, S.A.; Ene, E. FRAGSTATS v4: Spatial Pattern Analysis Program for Categorical and Continuous Maps; Computer software program produced by the authors at the University of Massachusetts, Amherst; University of Massachusetts: Amherst, MA, USA, 2012.

90. Kew, B.; Lee, B.D. Measuring sprawl across the urban rural continuum using an amalgamated sprawl index. Sustainability 2013, 5, 1806-1828. [CrossRef]

91. Laca, E.A. Multi-scape interventions to match spatial scales of demand and supply of ecosystem services. Front. Sustain. Food Syst. 2021, 4, 1-12. [CrossRef]

92. McGarigal, K.; Cushman, S.A. The Gradient Concept of Landscape Structure; Cambridge University Press: Cambridge, UK, 2005; pp. 112-119.

93. Li, H.; Wu, J. Landscape Pattern Analysis: Key Issues and Challenges; Cambridge University Press: Cambridge, UK, 2007 ; pp. 39-61.

94. Frazier, A.E. Emerging trajectories for spatial pattern analysis in landscape ecology. Landsc. Ecol. 2019, 34, 2073-2082. [CrossRef]

95. Reid, W.; Mooney, H.; Cropper, A.; Capistrano, D.; Carpenter, S.; Chopra, K. Millennium Ecosystem Assessment. Ecosystems and Human Well-Being: Synthesis; Island Press: Washington, DC, USA, 2005.

96. Haines-Young, R.P.M. Categorisation systems: The classification challenge. In Mapping Ecosystem Services; Burkhard, B., Ed.; Pensoft Publishers: Sofia, Bulgaria, 2017; pp. 44-47.

97. Bastian, O.; Grunewald, K.; Syrbe, R.-U.; Walz, U.; Wende, W. Land96scape services: The concept and its practical relevance. Landsc. Ecol. 2014, 29, 1463-1479. [CrossRef] 
98. Frei, B.; Renard, D.; Mitchell, M.G.E.; Seufert, V.; Chaplin-Kramer, R.; Rhemtulla, J.M.; Bennett, E.M. Bright spots in agricultural landscapes: Identifying areas exceeding expectations for multifunctionality and biodiversity. J. Appl. Ecol. 2018, 55, 2731-2743. [CrossRef]

99. Carpenter, S.R.; Mooney, H.A.; Agard, J.; Capistrano, D.; Defries, R.S.; Diaz, S.; Dietz, T.; Duraiappah, A.K.; Oteng-Yeboah, A.; Pereira, H.M.; et al. Science for managing ecosystem services: Beyond the millennium ecosystem assessment. Proc. Natl. Acad. Sci. USA 2009, 106, 1305-1312. [CrossRef] [PubMed]

100. Tallis, H.; Polasky, S. Mapping and valuing ecosystem services as an approach for conservation and natural-resource management. Ann. N. Y. Acad. Sci. 2009, 1162, 265-283. [CrossRef]

101. Rodríguez, J.P.; Beard, T.D., Jr.; Bennett, E.M.; Cumming, G.S.; Cork, S.J.; Agard, J.; Dobson, A.P.; Peterson, G.D. Trade-offs across space, time, and ecosystem services. Ecol. Soc. 2006, 11, 28. [CrossRef]

102. Bennett, E.M.; Peterson, G.D.; Gordon, L.J. Understanding relationships among multiple ecosystem services. Ecol. Lett. 2009, 12, 1394-1404. [CrossRef]

103. Powers, B.F.; Ausseil, A.-G.; Perry, G.L.W. Ecosystem service management and spatial prioritisation in a multifunctional landscape in the Bay of Plenty, New Zealand. Australas. J. Environ. Manag. 2020, 27, 275-293. [CrossRef]

104. Raudsepp-Hearne, C.; Peterson, G.D.; Bennett, E.M. Ecosystem service bundles for analyzing tradeoffs in diverse landscapes. Proc. Natl. Acad. Sci. USA 2010, 107, 5242-5247. [CrossRef]

105. Yang, G.; Ge, Y.; Xue, H.; Yang, W.; Shi, Y.; Peng, C.; Du, Y.; Fan, X.; Ren, Y.; Chang, J. Using ecosystem service bundles to detect trade-offs and synergies across urban-rural complexes. Landsc. Urban Plan. 2015, 136, 110-121. [CrossRef]

106. Lee, H.; Lautenbach, S. A quantitative review of relationships between ecosystem services. Ecol. Indic. 2016, 66, 340-351. [CrossRef]

107. Spyra, M.; La Rosa, D.; Zasada, I.; Sylla, M.; Shkaruba, A. Governance of ecosystem services trade-offs in peri-urban landscapes Land Use Policy 2020, 95, 104617. [CrossRef]

108. Gómez-Creutzberg, C.; Lagisz, M.; Nakagawa, S.; Brockerhoff, E.G.; Tylianakis, J.M. Consistent trade-offs in ecosystem services between land covers with different production intensities. Biol. Rev. Camb. Philos. Soc. 2021, 96, 1989-2008. [CrossRef] [PubMed]

109. Cushman, S.A.; McGarigal, K.; Neel, M.C. Parsimony in landscape metrics: Strength, universality, and consistency. Ecol. Indic. 2008, 8, 691-703. [CrossRef]

110. Darnhofer, I.; Fairweather, J.; Moller, H. Assessing a farm's sustainability: Insights from resilience thinking. Int. J. Agric. Sustain. 2010, 8, 186-198. [CrossRef]

111. Nassauer, J.I.; Opdam, P.F.M. Design in science: Extending the landscape ecology paradigm. Landsc. Ecology 2008, 23, 633-644. [CrossRef]

112. Burkhard, B.M., Jr. Mapping Ecosystem Services; Pensoft Publishers: Sofia, Bulgaria, 2017.

113. Baró, F.; Haase, D.; Gómez-Baggethun, E.; Frantzeskaki, N. Mismatches between ecosystem services supply and demand in urban areas: A quantitative assessment in five European cities. Ecol. Indic. 2015, 55, 146-158. [CrossRef]

114. Cortinovis, C.; Geneletti, D. Ecosystem services in urban plans: What is there, and what is still needed for better decisions. Land Use Policy 2018, 70, 298-312. [CrossRef]

115. Cortinovis, C.; Geneletti, D. A performance-based planning approach integrating supply and demand of urban ecosystem services. Landsc. Urban Plan. 2020, 201, 103842. [CrossRef]

116. Grêt-Regamey, A.; Rabe, S.-E.; Crespo, R.; Lautenbach, S.; Ryffel, A.; Schlup, B. On the importance of non-linear relationships between landscape patterns and the sustainable provision of ecosystem services. Landsc. Ecol. 2014, 29, 201-212. [CrossRef]

117. Haase, D.; Schwarz, N.; Strohbach, M.; Kroll, F.; Seppelt, R. Synergies, Trade-offs, and Losses of Ecosystem Services in Urban Regions: An Integrated Multiscale Framework Applied to the Leipzig-Halle Region, Germany. Ecol. Soc. 2012, 17, 22. [CrossRef]

118. Syrbe, R.-U.; Grunewald, K. Ecosystem service supply and demand-the challenge to balance spatial mismatches. Int. J. Biodivers. Sci. Ecosyst. Serv. Manag. 2017, 13, 148-161. [CrossRef]

119. Alberti, M. The effects of urban patterns on ecosystem function. Int. Reg. Sci. Rev. 2005, 28, 168-192. [CrossRef]

120. Cortinovis, C.; Geneletti, D. A framework to explore the effects of urban planning decisions on regulating ecosystem services in cities. Ecosyst. Serv. 2019, 38, 100946. [CrossRef]

121. Geneletti, D.; Esmail, B.A.; Cortinovis, C.; Arany, I.; Balzan, M.; Beukering, P.; Bicking, S.; Borges, P.; Burkhard, B.; Santos-Martín, F. Ecosystem services mapping and assessment for policy- and decision-making: Lessons learned from a comparative analysis of European case studies. One Ecosyst. Ecol. Sustain. Data J. 2020, 5, 1-31. [CrossRef]

122. Gómez-Creutzberg, C.; Tylianakis, J.; Greenhalgh, S.; Lagis, M.; Nakagawa, S.; Brockerhoff, E. Integrating Ecosystem Services in Land-Use Planning; Whenua, M., Ed.; Manaaki Whenua: Wellington, New Zealand, 2019.

123. Wezel, A.; Bellon, S.; Doré, T.; Francis, C.; Vallod, D.; David, C. Agroecology as a science, a movement and a practice. A review. Agron. Sustain. Dev. 2009, 29, 503-515. [CrossRef]

124. Gliessman, S.R. Agroecology: The Ecology of Sustainable Food Systems, 2nd ed.; CRC Press: Boca Raton, FL, USA, 2007.

125. Wezel, A.; Casagrande, M.; Celette, F.; Vian, J.-F.; Ferrer, A.; Peigné, J. Agroecological practices for sustainable agriculture. A review. Agron. Sustain. Dev. 2013, 34, 1-20. [CrossRef]

126. Duru, M.; Therond, O.; Martin, G.; Martin-Clouaire, R.; Magne, M.-A.; Justes, E.; Journet, E.-P.; Aubertot, J.-N.; Savary, S.; Bergez, J.-E.; et al. How to implement biodiversity-based agriculture to enhance ecosystem services: A review. Agron. Sustain. Dev. 2015, 35, 1259-1281. [CrossRef] 
127. Wezel, A.; Silva, E. Agroecology and agroecological cropping practices. In Agroecological Practices for Sustainable Agriculture: Principles, Applications, and Making the Transition; London World Scientific: London, UK, 2017.

128. Tittonell, P. Ecological intensification of agriculture-sustainable by nature. Curr. Opin. Environ. Sustain. 2014, 8, 53-61. [CrossRef]

129. Tittonell, P. Assessing resilience and adaptability in agroecological transitions. Agric. Syst. 2020, 184, 102862. [CrossRef]

130. Tscharntke, T.; Clough, Y.; Wanger, T.C.; Jackson, L.; Motzke, I.; Perfecto, I.; Vandermeer, J.; Whitbread, A. Global food security, biodiversity conservation and the future of agricultural intensification. Biol. Conserv. 2012, 151, 53-59. [CrossRef]

131. Altieri, M.A. Agroecology: The Science of Sustainable Agriculture, 2nd ed.; Westview Press: Boulder, CO, USA, 1995.

132. Vandermeer, J. The ecological basis of alternative agriculture. Annu. Rev. Ecol. Syst. 1995, 26, 201-224. [CrossRef]

133. Peeters, A.; Wezel, A. Agroecological principles and practices for grass-based farming systems. In Agroecological Practices for Sustainable Agriculture: Principles, Applications, and Making the Transition; Wezel, A., Ed.; London World Scientific: London, UK, 2017.

134. Kremen, C.; Miles, A. Ecosystem services in biologically diversified versus conventional farming systems: Benefits, externalities, and trade-offs. Ecol. Soc. 2012, 17, 40. [CrossRef]

135. Zhang, W.; Ricketts, T.H.; Kremen, C.; Carney, K.; Swinton, S.M. Ecosystem services and dis-services to agriculture. Ecol. Econ. 2007, 64, 253-260. [CrossRef]

136. Dominati, E.J.; Mackay, A.D.; Bouma, J.; Green, S. An ecosystems approach to quantify soil performance for multiple outcomes: The future of land evaluation? Soil Sci. Soc. Am. J. 2016, 80, 438-449. [CrossRef]

137. Raudsepp-Hearne, C.; Peterson, G.D.; Teng, M.; Bennett, E.M.; Holland, T.; Benessaiah, K.; MacDonald, G.K.; Pfeifer, L. Untangling the Environmentalist's paradox: Why is human well-being increasing as ecosystem services degrade? BioScience 2010, 60, 576-589. [CrossRef]

138. Bennett, E.M. Changing the agriculture and environment conversation. Nat. Ecol. Evol. 2017, 1, 18. [CrossRef]

139. Hatt, S.; Boeraeve, F.; Artru, S.; Dufrêne, M.; Francis, F. Spatial diversification of agroecosystems to enhance biological control and other regulating services: An agroecological perspective. Sci. Total Environ. 2018, 621, 600-611. [CrossRef]

140. Spake, R.; Lasseur, R.; Crouzat, E.; Bullock, J.M.; Lavorel, S.; Parks, K.E.; Schaafsma, M.; Bennett, E.M.; Maes, J.; Mulligan, M.; et al. Unpacking ecosystem service bundles: Towards predictive mapping of synergies and trade-offs between ecosystem services. Glob. Environ. Chang. 2017, 47, 37-50. [CrossRef]

141. Perrotti, D.; Iuorio, O. Green Infrastructure in the Space of Flows: An Urban Metabolism Approach to Bridge Environmental Performance and User's Wellbeing; Springer International Publishing: Cham, Switzerland, 2019; pp. 265-277.

142. Rolf, W.; Diehl, K.; Zasada, I.; Wiggering, H. Integrating farmland in urban green infrastructure planning. An evidence synthesis for informed policymaking. Land Use Policy 2020, 99, 104823. [CrossRef]

143. Hansen, R.; Pauleit, S. From multifunctionality to multiple ecosystem services? A conceptual framework for multifunctionality in green infrastructure planning for urban areas. Ambio 2014, 43, 516-529. [CrossRef]

144. De Block, G. Ecological infrastructure in a critical-historical perspective: From engineering 'social' territory to encoding 'natural' topography. Environ. Plan. A 2016, 48,367-390. [CrossRef]

145. Holt, A.R.; Alix, A.; Thompson, A.; Maltby, L. Food production, ecosystem services and biodiversity: We can't have it all everywhere. Sci. Total Environ. 2016, 573, 1422-1429. [CrossRef] [PubMed]

146. Dominati, E.J.; Maseyk, F.J.F.; Mackay, A.D.; Rendel, J.M. Farming in a changing environment: Increasing biodiversity on farm for the supply of multiple ecosystem services. Sci. Total Environ. 2019, 662, 703-713. [CrossRef]

147. Boeraeve, F.; Dendoncker, N.; Cornélis, J.-T.; Degrune, F.; Dufrêne, M. Contribution of agroecological farming systems to the delivery of ecosystem services. J. Environ. Manag. 2020, 260, 109576. [CrossRef] [PubMed]

148. DeClerck, F.; Estrada-Carmona, N.; Garbach, K.; Martinez-Salinas, A. Biodiversity and Ecosystem Services of Agricultural Landscapes: Reversing Agriculture's Externalities in FAO International Symposium-Agroecology for Food Security and Nutrition; FAO: Rome, Italy, 2014; pp. 140-157.

149. Garbach, K.; Milder, J.C.; DeClerck, F.A.J.; Montenegro de Wit, M.; Driscoll, L.; Gemmill-Herren, B. Examining multi-functionality for crop yield and ecosystem services in five systems of agroecological intensification. Int. J. Agric. Sustain. 2017, 15, 11-28. [CrossRef]

150. Tittonell, P. Beyond $\mathrm{CO}_{2}$ : Multiple Ecosystem Services From Ecologically Intensive Grazing Landscapes of South America. Front. Sustain. Food Syst. 2021, 5, 190. [CrossRef]

151. Mouchet, M.A.; Lamarque, P.; Martín-López, B.; Crouzat, E.; Gos, P.; Byczek, C.; Lavorel, S. An interdisciplinary methodological guide for quantifying associations between ecosystem services. Glob. Environ. Chang. 2014, 28, 298-308. [CrossRef]

152. Vandermeer, J.; Perfecto, I. Ecological complexity and agroecosystems: Seven themes from theory. Agroecol. Sustain. Food Syst. 2017, 41, 697-722. [CrossRef]

153. Tittonell, P. Livelihood strategies, resilience and transformability in African agroecosystems. Agric. Syst. 2014, 126, 3-14. [CrossRef]

154. Holling, C.S. Resilience of Ecosystems: Local Surprise and Global Change. In Global Change; Cambridge University Press: Cambridge, UK, 1985; pp. 228-269. 